\title{
Dynamics and diversity of newly produced virioplankton in the North Sea
}

\author{
Verónica Parada ${ }^{1}$, Anne-Claire Baudoux ${ }^{1}$, Eva Sintes ${ }^{1}$, Markus G Weinbauer ${ }^{2}$ \\ and Gerhard J Herndl ${ }^{1}$ \\ ${ }^{1}$ Department of Biological Oceanography, Royal Netherlands Institute for Sea Research, Texel, \\ The Netherlands and ${ }^{2}$ Laboratoire d'Océanographie de Villefranche, Université Pierre et Marie Curie \\ Paris VI, UMR 7093, Villefranche-sur-Mer, France
}

\begin{abstract}
Viral diversity has been studied in a variety of marine habitats and spatial and seasonal changes have been documented. Most of the bacteriophages are considered host specific and are thought to affect fast growing prokaryotic phylotypes more than slow growing ones. We hypothesized that viral infection and consequently, lysis occurs in pulses with only a few prokaryotic phylotypes lysed at any given time. Thus, we propose that the newly produced viruses represent only a fraction of the viral diversity present at any given time. Virioplankton diversity was assessed by pulsed-field gel electrophoresis in the surface waters of three distinct areas of the North Sea during the spring and summer. Bulk virioplankton diversity was fairly stable in these waters. Viral diversity produced by the indigenous bacterioplankton, however, exhibited day-to-day variability with only a few bands produced at any given time. These bands frequently matched bands of the in situ virioplankton; however, bands not present in the band pattern of the in situ virioplankton community were also found. These new bands probably indicate infection and subsequent release of viruses from bacterioplankton phylotypes previously not infected by these specific viruses. Overall, our results demonstrate that viral infection and lysis are rather dynamic processes. The main targets of viral infection are changing apparently on time scales of hours to days indicating that viral infection might effectively regulate and maintain bacterioplankton diversity.
\end{abstract}

The ISME Journal (2008) 2, 924-936; doi:10.1038/ismej.2008.57; published online 12 June 2008

Subject Category: microbial population and community ecology

Keywords: bacteriophages; newly produced viruses; North Sea; PFGE; viral community composition; viruses

\section{Introduction}

The dynamics in abundance and distribution of virioplankton have been extensively investigated since the notion emerged that they are orders of magnitude more abundant in the sea than previously assumed (Bergh et al., 1989; Weinbauer, 2004). Our understanding of virus diversity, however, is still in its infancy. Following the initial study on bacteriophage diversity in natural environments (Moebus, 1980), the introduction of an array of molecular tools confirmed the high diversity of marine bacteriophages (Wommack et al., 1999a; Steward et al., 2000; Angly et al., 2006).

Viruses have no universally conserved genetic elements such as eukaryotes or prokaryotes. Thus, it is not possible to use PCR-based approaches combined with fingerprinting techniques such as

Correspondence: GJ Herndl, Department of Biological Oceanography, Royal Netherlands Institute for Sea Research, PO Box 59, AB 1790 Den Burg, Texel, The Netherlands.

E-mail: herndl@nioz.nl

Received 13 March 2008; revised 13 May 2008; accepted 15 May 2008; published online 12 June 2008
T-RFLP and DGGE to assess the richness of viral communities. However, some specific primers have been developed to determine cyanophage diversity in aquatic systems targeting the pol gene encoding DNA polymerase or a region of the capsid assembly protein gene (Chen and Suttle, 1995; Chen et al., 1996). From the sequences obtained for viral communities, $65 \%$ did not have homologues in the GenBank database, suggesting a large, thus far, unrecognized viral diversity (Breitbart et al., 2002). The homologues found included the major families of tailed phages with double-stranded DNA genomes (which dominate marine virioplankton) and algal viruses. Several studies suggest an enormous viral community richness with few phages dominating, similar to bacterioplankton (Lanoil et al., 2000).

Pulsed-field gel electrophoresis (PFGE) is a more general fingerprinting approach to characterize viral richness in natural communities than hybridization approaches (Klieve and Bauchop, 1988; Wommack et al., 1999a; Steward et al., 2000; Riemann and Middelboe, 2002; Jiang et al., 2003). PFGE is based on size fractionation of intact DNA. No a priori knowledge of common traits of the viral community 
is required. This method has the drawback of not recovering the ssRNA and ssDNA viruses, although it is known that most of the phages that infect marine bacteria are dsDNA and are therefore covered by the PFGE approach (Wommack et al., 1999a). More important, several different phage types can be found within a genome size class. Nevertheless, studies have shown that this approach is useful in detecting changes in the viral community.

Most bacteriophages are considered host specific (Ackermann, 1987). The infection rate of a given bacterial phylotype is therefore dependent on the abundance of the bacterial host. Thus, the more abundant the bacterial host, the higher the chance for a specific viral population to infect its host. These considerations led to the formulation of the killing-the-winner hypothesis (Thingstad and Lignell, 1997). It postulates that selective viral infection of the most abundant bacterial phylotype ensures that other phylotypes with a similar ecological niche can coexist despite being potentially less efficient in utilizing the available resources thus, allowing niche partitioning. Therefore, according to this concept, selective viral infection of bacteria ensures a higher evenness of phylotypes in a given bacterial community. This implies explicitly, however, that the main target phylotype for viral infection varies over time and that only a fraction of the viral community is infecting hosts at high rates at any given time. Considering that the richness of bacteriophages in coastal surface waters is relatively high (Wommack et al., 1999b) and that the decay of viruses in surface waters is in the range of 1-2 days (Heldal and Bratbak, 1991; Wilhelm et al., 1998), a rapid succession of infection targets can be assumed and consequently, a tight control of bacterioplankton evenness by bacteriophages. These temporal dynamics in viral infection and phage production have been addressed only on short-time scales (Bettarel et al., 2002; Winter et al., 2004) but viral diversity was not analyzed thus far and is subject of this study.

We hypothesized that viral infection and consequently lysis occurs in pulses with only a few prokaryotic phylotypes lysed at any given time. Consequently, the newly produced viruses, resulting from these infection pulses, resemble only a fraction of the total viral richness present in situ at any given time. Due to viral decay rates in the order of days, the main targets of viral infection should switch within hours to days to maintain the observed richness of the viral community commonly detected in natural waters.

\section{Materials and methods}

Sampling areas

During the MOMAP-2 cruise with R/V Pelagia (July 2003), individual water masses of the open North
Sea were followed by deploying a drifting buoy at three sampling stations (Sts 1-3) over a period of $28 \mathrm{~h}$ (Sts 1, 3) or $48 \mathrm{~h}$ (St 2; Figure 1). Sts 4 and 5 were sampled only once. At Sts 1-3, water samples were taken at $4 \mathrm{~h}$ intervals to determine the diel dynamics of virioplankton abundance and viral community composition. Water samples were collected from $5 \mathrm{~m}$ depth with 10-l NOEX bottles mounted on a rosette sampler holding also sensors for temperature, depth, conductivity, chlorophyll fluorescence and optical backscattering.

During a Phaeocystis sp. bloom in May/June 2004, surface water (5l) of the coastal North Sea was collected from the NIOZ-jetty from about $0.5 \mathrm{~m}$ depth using an acid-rinsed bucket over consecutive days for a 2 weeks period. This sampling was intended to determine the short-term variability of the newly produced virioplankton community in coastal North Sea waters when the bacterioplankton dynamics and activity are high. Aged North Sea water $(20 \mathrm{l})$, stored at room temperature under dim light conditions for 1 year, was also sampled over several consecutive days in order to assess the dynamics in viral abundance and community composition in a presumably stable system.

\section{Preparation of viral concentrates to assess viral diversity by pulsed-field gel electrophoresis}

During the MOMAP-2 cruise, 201 of seawater was filtered through $0.8 \mu \mathrm{m}$ pore-size polycarbonate filters (Isopore ATTP, $142 \mathrm{~mm}$ diameter, Millipore, Millford, MA, USA) using a stainless-steel filter holder (Sartorius) and an air-pressure pump to remove most of the nonliving particles and phytoplankton. Subsequently, the particles in the $0.8 \mu \mathrm{m}$ filtrate were concentrated to a final volume of approximately $600 \mathrm{ml}$ using tangential-flow filtration cartridge (Vivaflow 200, $0.22 \mu \mathrm{m}$ pore size, Vivascience, Lincoln, UK). The $0.22 \mu \mathrm{m}$ filtrate was further processed using a $30 \mathrm{kDa}$ ultrafiltration cartridge (Vivascience) to obtain a virus-free ultrafiltrate and a virus concentrate (Winter et al., 2004). Both, the $0.2 \mu \mathrm{m}$ and the $30 \mathrm{kDa}$ filtrations were operated using peristaltic pumps (Masterflex) at a maximum pressure of 2 bar. The entire filtration procedure was performed at in situ temperature within $1 \mathrm{~h}$ after collecting the sample. The viral concentrate was kept at $-20^{\circ} \mathrm{C}$ until further processing in the home laboratory.

Upon return to the home laboratory, the virus concentrate was pelleted by ultracentrifugation at $141000 \mathrm{~g}$ in a fixed angle rotor (TFT 55.38, Centrikon T-1080, Kontron Instruments) at $8{ }^{\circ} \mathrm{C}$ for $2 \mathrm{~h}$. Pellets were resuspended and incubated overnight at $4{ }^{\circ} \mathrm{C}$ in $\mathrm{SM}$ buffer $\left(0.1 \mathrm{M} \mathrm{NaCl}, 8 \mathrm{mM} \mathrm{MgSO}_{4} 7 \mathrm{H}_{2} \mathrm{O}\right.$, $50 \mathrm{mM}$ Tris- $\mathrm{HCl}$ and $0.005 \%(\mathrm{w} / \mathrm{v}$ ) glycerol) (Wommack et al., 1999a). Equal volumes of the viral concentrate were mixed with melted $\left(50^{\circ} \mathrm{C}\right) 1.5 \%$ InCert agarose (Cambrex Bioscience, Rockland, $\mathrm{ME}$, USA) and loaded into plugs. The plugs were 


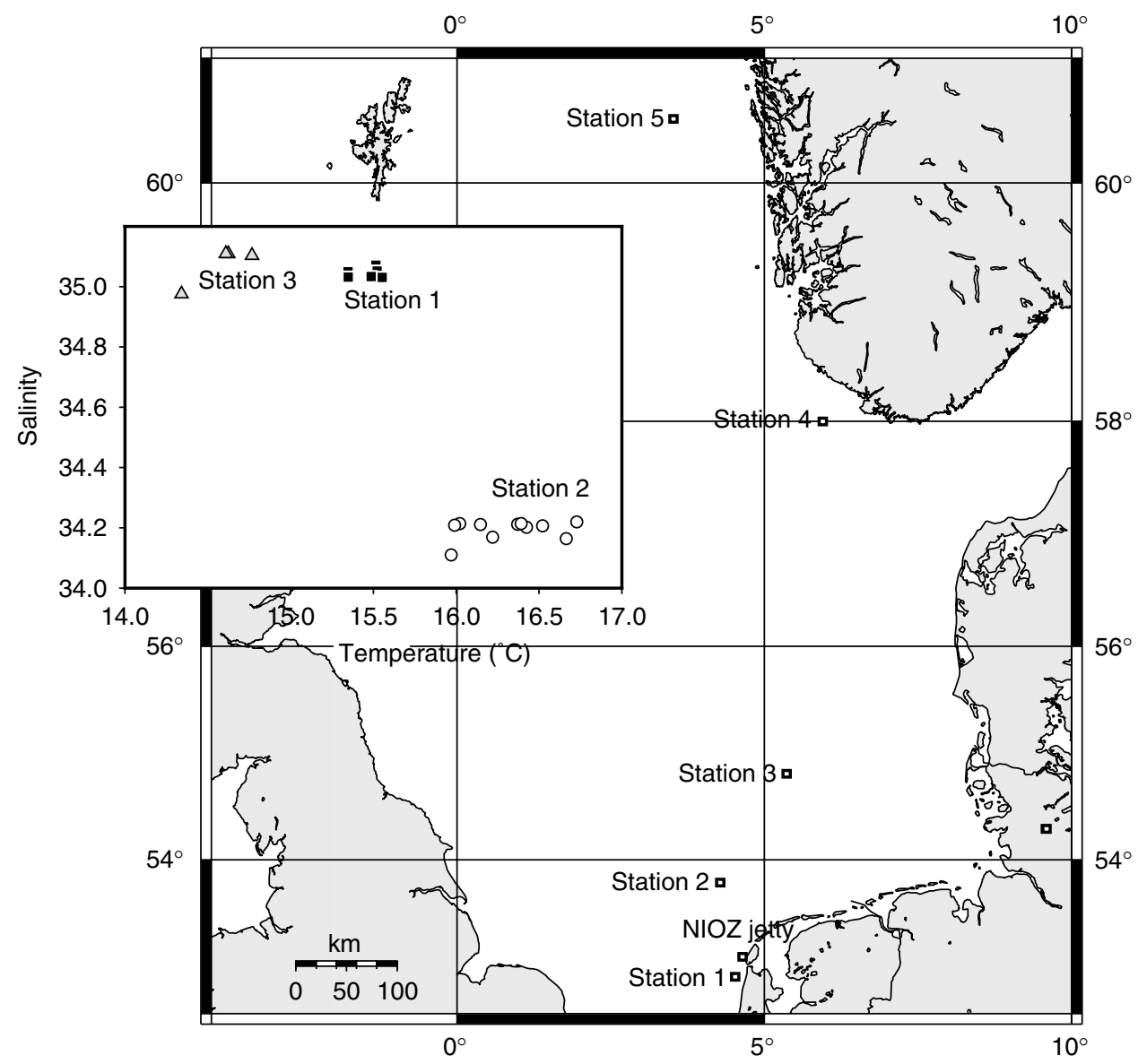

Figure 1 Map of the study area indicating the two main sampling sites: the open North Sea waters sampled during the MOMAP cruise in 2003 (stations (Sts) 1-5) and coastal North Sea waters sampled from the NIOZ jetty. The salinity-temperature signature of Sts 1-3 sampled over diel cycles is shown in the inset. The date and time of sampling are given for each station in Table 1.

digested overnight at $30^{\circ} \mathrm{C}$ in a lysis buffer $(250 \mathrm{mM}$ EDTA, $1 \%$ SDS v/v, $1 \mathrm{mg} \mathrm{ml}^{-1}$ proteinase K, SigmaAldrich, St Louis, MO, USA). Then, the plugs were washed three times in TE 10:1 buffer (10 mM Tris$1 \mathrm{mM}$ EDTA, $\mathrm{pH}$ 8.0) for $30 \mathrm{~min}$ and stored in TE 20:50 buffer (20 mM Tris-50 mM EDTA, pH 8.0) at $4{ }^{\circ} \mathrm{C}$ until loading onto the gel. The molecular weight markers, a lambda ladder and a $5 \mathrm{~kb}$ ladder (Bio-Rad, Richmond, CA, USA) were also loaded into plugs.

Plugged samples and markers were placed into wells of a 1\% SeaKem GTG agarose gel (Cambrex Bioscience) prepared in $1 \times \mathrm{TBE}$ gel buffer $(90 \mathrm{~mm}$ Tris-Borate, $1 \mathrm{mM}$ EDTA, pH 8.0) with an overlay of melted $1 \%$ agarose. PFGE was performed with the contour-clamped homogenous electric field DR-II Cell (Bio-Rad) at 1-6 s pulse ramp, $6 \mathrm{~V} \mathrm{~cm}^{-1}$ set at $14{ }^{\circ} \mathrm{C}$ for $20 \mathrm{~h}$. After electrophoresis, the gels were stained with SYBR-Green I (Molecular Probes Inc., Eugene, OR, USA) for $60 \mathrm{~min}$ and destained in Milli$\mathrm{Q}$ water for $10 \mathrm{~min}$ (Gradient A10, Millipore). Then, the gel was digitally scanned for fluorescence using a FluorS Imager (Bio-Rad).

Each of the virioplankton PFGE fingerprints was normalized against the background fluorescence to quantify the signal intensity of each band. By comparing the bands with the size-standard of a known amount of DNA, the relative abundance of each viral population corresponding to a specific genome size was calculated. The staining intensity and genome size were related to the number of viruses loaded into each plug (Paul, 2001).

Throughout the paper, we determined the diversity of viral communities as obtained from water samples of the North Sea (termed 'in situ' viral diversity) and the viral diversity obtained by the virus-reduction approach using water from the respective sampling site collected at different days. The viral community, obtained by the virus-dilution approach represents the viruses produced at a specific date or time of the day at the respective sampling site, is termed 'newly produced' viral diversity and compared with the indigenous 'in situ' viral diversity.

\section{Viral production}

The virus-reduction approach was used to measure viral production (VP) (Weinbauer and Suttle, 1996). Briefly, bacterial concentrates were prepared after prefiltration through $0.8 \mu \mathrm{m}$ pore-size polycarbonate 
filters using a Vivaflow-200 tangential flow system holding a $0.2 \mu \mathrm{m}$ pore-size polycarbonate cartridge. To obtain virus-free seawater, $0.2 \mu \mathrm{m}$ pore-size filtered seawater was passed through another Vivaflow-200 cartridge with a $30 \mathrm{kDa}$ molecular weight cutoff filter. Bacterial concentrates were brought up to the original volume with virus-free seawater and incubated at in situ temperature in the dark. Subsamples were taken to enumerate bacteria and viruses at regular intervals (4-6 h) for a total period of up to $24 \mathrm{~h}$. Experiments were performed in triplicate. VP was calculated as the slope of a firstorder regression line of viral abundance versus incubation time (Wilhelm et al., 2002). The loss of bacterial hosts was corrected by multiplying the VP by the ratio between the bacterial abundance in the original samples prior to the filtration step and the initial bacterial abundance in the virus-reduction incubations.

\section{Enumeration of bacterial and viruses}

Bacteria and viruses were enumerated using flow cytometry. Samples $(2 \mathrm{ml})$ were fixed with glutaraldehyde $(0.5 \%$ final concentration), shock-frozen in liquid nitrogen for $5 \mathrm{~min}$ and stored at $-80^{\circ} \mathrm{C}$. Bacterial cells and viral particles were stained with SYBR-Green I and enumerated with a FACSCalibur flow cytometer (Becton Dickinson, Franklin Lakes, NJ, USA) as described previously (Marie et al., 1999; Brussaard, 2004). Briefly, the samples for enumerating viruses were thawed immediately before analysis, diluted 10- to 100-fold in TE buffer (Tris $10 \mathrm{mM}$, EDTA $1 \mathrm{mM}, \mathrm{pH}$ 8) and stained with SYBR-Green I added at a 200 -fold final dilution of the commercial stock at $80^{\circ} \mathrm{C}$ in the dark for $10 \mathrm{~min}$. The thawed bacterial samples were diluted 5- to 10-fold in TE buffer and stained with SYBR-Green I at room temperature in the dark for $15 \mathrm{~min}$. Fluorescent microspheres (Molecular Probes Inc.) with a diameter of $0.95 \mu \mathrm{m}$ were added to all samples as an internal standard. The discriminator was set on green fluorescence and the samples were analyzed at a viral event rate between 100 and $1000 \mathrm{~s}^{-1}$ for 1 min. The bacterial abundance obtained by flow cytometry was compared to that obtained by epifluorescence microscopy (data not shown). Both methods yielded similar results $(<10 \%$ deviation).

\section{Bacterial production}

Bulk bacterial production (BP) was measured only in open North Sea waters during the MOMAP-2 cruise by incubating $5 \mathrm{ml}$ of water in duplicate and one formaldehyde-killed blank ( $2 \%$ final concentration) with $20 \mathrm{nM}\left[{ }^{3} \mathrm{H}\right]$ leucine (final concentration, SA $157 \mathrm{Ci} \mathrm{mmol}^{-1}$; Amersham, Little Chalfont, Buckinghamshire, UK) in the dark at in situ temperature for $4 \mathrm{~h}$. Thereafter, the incubation was terminated by adding formaldehyde ( $2 \%$ final concentration) to the samples. Then, the samples and the blank were filtered through $0.2 \mu \mathrm{m}$ polycarbonate filters (Millipore, $25 \mathrm{~mm}$ filter diameter). Subsequently, the filters were twice rinsed with $5 \%$ ice-cold trichloroacetic acid, placed in scintillation vials and stored at $-20^{\circ} \mathrm{C}$ until counting in a liquid scintillation counter. The disintegrations per minute (DPM) of the formaldehyde-fixed blank were subtracted from the mean DPM of the samples and the resulting DPM converted into leucine incorporation rates.

\section{Estimation of other viral parameters}

Specific parameters were only calculated for the open North Sea waters.

Burst size. We used the burst size (BS), that is, the number of phages released per host cell during lysis, given in Winter et al. (2004) who determined the minimum BS in the same area as covered by this study using transmission electron microscopy. Their BS estimates were used for calculating virally mediated mortality (VMB) in the open North Sea as described below. The average BS reported by Winter et al. (2004) was 21 for St 1, 31 for St 2 and 22 for St 3 (Table 1).

Viral-mediated mortality of bacteria. VMM was calculated from the VP divided by the BS for each sampling site in the open North Sea (Helton et al. 2005).

Fraction of bacterial production lysed by viruses. The percentage of BP lysed by viruses per day was calculated from BP (cells per liter per day) divided by VMM (Helton et al., 2005; Winget et al., 2005).

Viral and bacterial turnover rate. Viral (VTR) and bacterial turnover rates (BTR) per day were calculated by dividing the average viral and BP per day by the average viral and bacterial abundance, respectively.

\section{Statistical analyses}

Pearson's correlation coefficients were calculated to test relationships between parameters. To evaluate differences within and between stations or sampling times, Kruskal-Wallis one-way analysis of variance (ANOVA) on ranks was used. The results of statistical tests were considered significant at a $P$-value $<0.05$.

The similarities of the PFGE patterns between the different stations were assessed with the Whitaker's index of association $\left(S_{\mathrm{w}}\right.$; Whittaker, 1952) that compares the relative amount of viral DNA fluorescence associated with each band as described by the following equation:

$$
S_{W}=1-0.5 * \sum\left|b_{i 1}-b_{i 2}\right|
$$

where $b_{1}$ and $b_{2}$ are the decimal fractions of the relative viral abundance of the ith band in samples 1 
Table 1 Bacterial and viral parameters of the open North Sea collected at $5 \mathrm{~m}$ depth at several stations during the MOMAP-1 cruise

\begin{tabular}{|c|c|c|c|c|c|c|c|c|c|c|}
\hline $\begin{array}{l}\text { Date }(\mathrm{dd} / \mathrm{mm}, \\
\text { time) }\end{array}$ & $\begin{array}{l}\text { BA (10 cells } \\
\text { per liter })\end{array}$ & $\begin{array}{c}V A\left(10^{10}\right. \\
\text { cells per liter) }\end{array}$ & $V A / B A$ & $\begin{array}{c}B P\left(10^{8} \text { cells }\right. \\
\text { per liter per day })\end{array}$ & $\begin{array}{l}V P\left(10^{8} \text { cells per }\right. \\
\text { liter per day })\end{array}$ & $B S$ & $\begin{array}{l}V M M\left(10^{8} \text { cells }\right. \\
\text { per day })\end{array}$ & $\begin{array}{l}\% \text { BP } \\
\text { lysed }\end{array}$ & $\begin{array}{c}V T R \\
\text { (per day) }\end{array}$ & $\begin{array}{l}\text { GR (per } \\
\text { day) }\end{array}$ \\
\hline \multicolumn{11}{|l|}{ Station 1} \\
\hline 09/07, 04:00 & $4.63 \pm 0.2$ & $1.09 \pm 0.09$ & 23 & 1.86 & 15.15 & 21 & 0.72 & 2.58 & 0.33 & 0.46 \\
\hline $09 / 07,08: 30$ & $5.45 \pm 0.0$ & $1.00 \pm 0.08$ & 18 & 1.64 & & & & & & 0.34 \\
\hline 09/07, 13:15 & $5.65 \pm 0.6$ & $0.79 \pm 0.06$ & 14 & 1.55 & 20.85 & 21 & 0.99 & 1.56 & 0.50 & 0.31 \\
\hline 09/07, 16:00 & $5.94 \pm 0.3$ & $0.96 \pm 0.07$ & 16 & 1.96 & 6.28 & 21 & 0.30 & 6.57 & 0.29 & 0.38 \\
\hline $09 / 07,20: 00$ & $6.13 \pm 0.2$ & $4.46 \pm 0.11$ & 73 & 2.17 & 12.65 & 21 & 0.60 & 3.60 & 0.19 & 0.40 \\
\hline 10/07, 00:00 & $6.09 \pm 0.3$ & $4.47 \pm 0.09$ & 73 & 0.70 & 2.52 & 21 & 0.12 & 5.82 & 0.21 & 0.13 \\
\hline $10 / 07,04: 00$ & $6.95 \pm 0.2$ & $0.80 \pm 0.10$ & 11 & 2.06 & 252.52 & 21 & 12.02 & 0.17 & 0.19 & 0.34 \\
\hline $10 / 07,08: 00$ & $6.97 \pm 0.2$ & $0.70 \pm 0.02$ & 10 & 0.66 & 0.99 & 21 & 0.05 & 13.86 & 0.23 & 0.11 \\
\hline $10 / 07,13: 15$ & $6.28 \pm 0.5$ & $1.00 \pm 0.05$ & 16 & 2.10 & 1.69 & 21 & 0.08 & 26.01 & 0.24 & 0.38 \\
\hline $10 / 07,16: 00$ & $5.31 \pm 1.1$ & $3.52 \pm 0.04$ & 66 & 1.91 & 62.98 & 21 & 3.00 & 0.64 & 0.28 & 0.41 \\
\hline Average & $5.9 \pm 0.7$ & $1.8 \pm 1.6$ & $32 \pm 27$ & $1.66 \pm 0.6$ & $42 \pm 81$ & 21 & $2 \pm 3.9$ & $7 \pm 8.3$ & $0.27 \pm 0.1$ & $0.33 \pm 0.1$ \\
\hline \multicolumn{11}{|l|}{ Station 2} \\
\hline 11/07, 04:00 & $7.23 \pm 0.3$ & $1.08 \pm 0.02$ & 15 & 1.13 & 17.92 & 31 & 0.58 & 1.96 & 0.20 & 0.18 \\
\hline 11/07, 08:00 & $6.60 \pm 0.2$ & $0.93 \pm 0.07$ & 14 & 1.14 & & & & & & 0.20 \\
\hline $11 / 07,13: 15$ & $6.75 \pm 0.8$ & $0.84 \pm 0.03$ & 12 & 0.88 & 14.27 & 31 & 0.46 & 1.91 & 0.20 & 0.15 \\
\hline $11 / 07,16: 00$ & $5.51 \pm 0.3$ & $1.02 \pm 0.01$ & 19 & 0.84 & & & & & & 0.17 \\
\hline $11 / 07,20: 00$ & $4.30 \pm 0.3$ & $1.69 \pm 0.04$ & 39 & 0.91 & 0.00 & 31 & 0.00 & 0.00 & 0 & 0.24 \\
\hline $12 / 07,00: 00$ & $3.94 \pm 0.3$ & $0.88 \pm 0.04$ & 22 & 0.80 & & & & & & 0.23 \\
\hline 12/07, 04:00 & $4.49 \pm 0.2$ & $1.01 \pm 0.03$ & 22 & 0.09 & 53.09 & 31 & 1.71 & 0.05 & 2.22 & 0.02 \\
\hline $12 / 07,08: 00$ & $4.30 \pm 0.5$ & $0.94 \pm 0.02$ & 22 & 0.71 & & & & & & 0.19 \\
\hline 12/07, 13:15 & $3.86 \pm 0.1$ & $0.89 \pm 0.03$ & 23 & 0.52 & 0.66 & 31 & 0.02 & 24.48 & 0.26 & 0.15 \\
\hline $12 / 07,16: 00$ & $3.61 \pm 1.4$ & $0.91 \pm 0.04$ & 25 & 0.68 & & & & & & 0.21 \\
\hline $12 / 07,20: 00$ & $3.46 \pm 0.8$ & $0.80 \pm 0.02$ & 23 & 0.67 & 1.47 & 31 & 0.05 & 14.08 & 0.80 & 0.22 \\
\hline 13/07, 00:00 & $3.09 \pm 0.6$ & $0.84 \pm 0.07$ & 27 & 0.60 & & & & & & 0.22 \\
\hline 13/07, 04:00 & $2.98 \pm 0.6$ & $1.00 \pm 0.11$ & 33 & 0.16 & 30.41 & 31 & 0.98 & 0.16 & 1.47 & 0.06 \\
\hline Average & $4.6 \pm 1.4$ & $0.9 \pm 0.2$ & $22 \pm 7.4$ & $0.70 \pm 0.3$ & $17 \pm 19$ & 31 & $0.5 \pm 0.6$ & $6 \pm 9.5$ & $0.45 \pm 0.8$ & $0.17 \pm 0.1$ \\
\hline \multicolumn{11}{|l|}{ Station 3} \\
\hline $14 / 0,04: 00$ & $2.37 \pm 0.0$ & $0.49 \pm 0.02$ & 21 & 0.80 & 133.00 & 22 & 6.05 & 0.13 & 1.66 & 0.39 \\
\hline 14/07, 08:00 & $2.80 \pm 0.0$ & $0.69 \pm 0.01$ & 25 & 0.69 & & & & & & 0.28 \\
\hline $14 / 07,13: 15$ & $3.20 \pm 0.6$ & $0.50 \pm 0.01$ & 16 & 0.92 & 11.95 & 22 & 0.54 & 1.70 & 0.26 & 0.33 \\
\hline $14 / 07,16: 00$ & $3.16 \pm 0.0$ & $0.68 \pm 0.03$ & 22 & 0.93 & & & & & & 0.34 \\
\hline $14 / 07,20: 00$ & $3.26 \pm 0.7$ & $0.75 \pm 0.05$ & 23 & 0.60 & 3.85 & 22 & 0.18 & 3.40 & 0.25 & 0.21 \\
\hline 15/07, 00:00 & $3.11 \pm 1.8$ & $0.51 \pm 0.01$ & 16 & 0.72 & & & & & & 0.27 \\
\hline 15/07, 04:00 & $3.37 \pm 1.8$ & $0.48 \pm 0.02$ & 14 & 0.69 & 0.83 & 22 & 0.04 & 18.33 & 0.31 & 0.23 \\
\hline Average & $3.0 \pm 0.3$ & $0.5 \pm 0.1$ & $19 \pm 4.2$ & $0.76 \pm 0.1$ & $37 \pm 63$ & 22 & $1.7 \pm 2.9$ & $6 \pm 8.4$ & $0.6 \pm 0.7$ & $0.2 \pm 0.1$ \\
\hline
\end{tabular}

Abbreviations: BA, bacterial abundance; BP, bacterial cell production; BS, burst size (from Winter et al., 2004); GR, bacterial growth rate; VA, viral abundance; VMM, viral-mediated cell mortality; VP, viral production; VTR, viral turnover rate.

Averages and standard errors ( \pm s.e.) of triplicate measurements are given for each station. Data for stations 4 and 5 are not shown. For the location of the stations see Figure 1. 
and 2, respectively. $S_{\mathrm{w}}$ scales from 0 (completely different) to 1 (identical). Dendrograms of the PFGE patterns were constructed using the similarity matrix of $S_{\mathrm{w}}$ values and computed using the XLSat plugin (Addinsoft SARL) with the unweighted pairgroup method with arithmetic averages (Wommack et al., 1999a; Hewson and Fuhrman, 2006).

Whenever the relative abundance of viruses corresponding to each band could not be calculated due to saturated-pixel images, the similarity matrices were constructed from the Dice's index (Dice, 1945) that considers only the presence or absence of bands. The diversity of viral communities was assessed by the Shannon-Weaver index and the ratio of the observed diversity to the maximum diversity was taken as a measure of evenness (Ludwig and Reynolds, 1988; Magurran, 1995). The number of bands was used to calculate Margalef's index (Ludwig and Reynolds, 1988) and to determine the richness of the viral community.

\section{Results}

Characteristics of the open North Sea water masses During the diel sampling following specific water masses with the drifting buoy, salinity and temperature fluctuated only over a rather narrow range at Sts 1 and 3 (Figure 1) indicating that distinct parcels of water were sampled over time. The relatively large variation in temperature at St 2 indicates, however, that this water body mixed to a certain extent with surrounding waters during the course of the diel sampling.

Diel dynamics of virioplankton in the open North Sea Viral and bacterial abundance and production. The mean abundance of virus-like particles (VLP) and bacteria for each station and sampling time is given in Table 1 . The abundance of bacteria ranged from 2.37 to $7.23 \times 10^{8}$ per liter and viral abundance from 0.48 to $4.47 \times 10^{10}$ per liter, resulting in an average virus-to-bacteria ratio of 25 . The widest range of the virus-to-bacteria ratio was observed at St 1 (10-73) over the diel sampling (Table 1). At St 1, viral abundance displayed a pronounced peak during the night, whereas bacterial abundance remained fairly constant (Table 1). At St 2, viral abundance exhibited one small peak in late afternoon whereas bacteria overall decreased to about half of their initial abundance over the $48 \mathrm{~h}$ sampling period (Table 1). Only small fluctuations were detectable in viral and bacterial abundance at St 3 (Table 1).

Bacterial cell production ranged from 0.09 to $2.17 \times 10^{8}$ cells per liter per day and VP from 0 to $253 \times 10^{8}$ VLP per liter per day (Table 1). The highest VMM was recorded at all stations during the night, coinciding with high BP rates at Sts 1 and 3 and low $\mathrm{BP}$ at St 2. No relation between BP and VP was detected at any station $\left(r^{2}<0.247\right)$. However, a weak positive correlation $\left(r^{2}=0.327, P<0.05, n=30\right)$ was found between viral abundance and BP when all the data from the three stations were pooled. Viral and bacterial abundance were also positively related when the data from the three stations were pooled $\left(r^{2}=0.334, P<0.05, n=30\right)$.

Viral diversity in the open North Sea: in situ versus newly produced. The in situ viral diversity and the newly produced viral diversity were determined by sampling over a diel cycle. An example of the resulting banding pattern is shown for St 2 in Figure 2a. The electrophoretic conditions were adjusted to different settings (20-40 s pulse ramp, $200 \mathrm{~V}, 14^{\circ} \mathrm{C}$ and $22 \mathrm{~h}$ ) to spread the broad smear of DNA $>150 \mathrm{~kb}$ present in all the gels out into discrete bands; however, no extra bands could be discriminated (data not shown). The detection limit for this particular environment was $10^{9}$ viruses per plug as determined with different viral concentrations.

Pooling all the data obtained, the number of bands of the in situ viral community $(9 \pm 5)$ was significantly higher than the number of newly produced bands $(1.6 \pm 0.8)$ along all the stations in the transect ( $t$-test, $P=0.020)$. The banding patterns obtained for the in situ viral community ranged in molecular size between 30 and $280 \mathrm{~kb}$ (data not shown). Only the bands between 30 and $80 \mathrm{~kb}$ were used for more detailed analyses as the bands $>80 \mathrm{~kb}$ comprised only $0.1 \%$ of total signal intensity. The PFGE fingerprint patterns of the in situ viral community were more similar at the individual stations sampled at different times of the day than between stations (Figure 2b).

The obtained PFGE pattern for the newly produced viruses revealed only two to three bands produced at a given time at all the stations. As exemplified in Figure 2a for St 2, some of the newly produced bands were also present in the in situ virioplankton community at specific times, whereas at other sampling times they were not present in the in situ viral community (Figure 2a). Some of the newly produced viral populations displayed intense bands indicative of a high abundance of bacteriophages following lysis. This high number of viruses generated bands with saturated-pixel images and hence, was not quantifiable.

The abundance of individual viral populations can be quantified from the intensity of the individual band (Figure 3). The abundance of the different viral populations varied between stations and sampling times. At St 1, viruses with a genome size of 35 and $65 \mathrm{~kb}$ displayed the highest relative abundance, with minor representatives of 30 and $55 \mathrm{~kb}$ (Figure 3a). At St 2, the viral population with $35 \mathrm{~kb}$ was the most abundant, although viruses of $30 \mathrm{~kb}$ and between 55 and $65 \mathrm{~kb}$ were also present (Figure 3b). At St 3, the viral populations with 35 and $40 \mathrm{~kb}$ were most abundant, followed by 
viruses of 60 and $65 \mathrm{~kb}$ (Figure 3c). The viral population of $35 \mathrm{~kb}$ made up almost $50 \%$ of the total viral abundance at St $4 \%$ and $82 \%$ at St 5 (Figure 3c).

The Shannon-Weaver index for open North Sea viral communities varied from 0.59 to 1.89 (1.33 \pm 0.47$)$, indicating a high variability in the diversity of the viral community between the different stations whereas there were only small differences detectable at the individual stations over diel cycles (Figure 4a). The evenness component of the fingerprint diversity and richness calculated with Margalef's index ranged from 0.37 to 0.81 $(0.65 \pm 0.14)$ and from 0.15 to $0.85(0.39 \pm 0.26)$, respectively. Viral richness was positively related to bacterial cell production $\left(r^{2}=0.68\right)$ as shown in Figure $4 b$.

Dynamics of virioplankton in the coastal North Sea Viral abundance and activity. The viral abundance averaged $6.8 \times 10^{10}$ VLP per liter during the whole sampling period (second half of May) ranging from 5.5 to $8.8 \times 10^{10}$ VLP per liter (Table 2 ). The average virus-to-bacteria ratio was 23 (range, 9-27). Mean VP amounted to $10.8 \pm 10.4 \times 10^{10}$ VLP per liter per day (mean \pm s.d.) ranging from $1.2 \times 10^{10}$ to $35 \times 10^{10}$ VLP per liter per day. The highest VP coincided with high mortality of bacteria but not with the abundance of viruses (Table 2). No relation was found between the frequency of infected cells and $\mathrm{BP}$.

Viral diversity in the coastal North Sea: in situ versus newly produced. Substantial differences in the number of bands and genome size were detected between the viral diversity present in situ and that newly produced. A total of nine bands were detected for the viral community present in situ ranging from 20 to $>200 \mathrm{~kb}$. Most of the in situ samples collected for each date were accidentally lost, so only one in situ banding pattern is shown in Figure 5a.

Based on the fingerprint pattern, the ShannonWeaver index for the viral community present in situ ranged from 0.67 to $1.77(1.41 \pm 0.3)$ fluctuating within a lower range than in the open North Sea (Figure 4c). The fingerprint richness, calculated

Figure 2 (a) Pulsed-field gel electrophoresis (PFGE) fingerprints of virioplankton representing open North Sea water collected at St 2 (upper panel) and the corresponding computer-generated banding pattern (center panel). The fingerprints originate from different gels. Thus, for each lane the corresponding ladder is also shown. Lanes A and B correspond to $5 \mathrm{~kb}$ and lambda ladder, respectively. The PFGE fingerprints of the in situ (IS) and the newly produced (np) viral populations are shown and denoted with the subscripts a, b and c indicating the sampling times 0200 , 0600 and 0200 hours (next day), respectively. The molecular sizes are in kilobases. (b) Similarity matrix of the in situ virioplankton PFGE fingerprint. with the Margalef's index, ranged from 0.06 to 0.32 $(0.22 \pm 0.7)$ and the evenness index from 0.97 to 0.84 $(0.91 \pm 0.04)$.

The obtained PFGE pattern for the newly produced viruses revealed a maximum of seven bands. These bands were also present in the fingerprints of

a

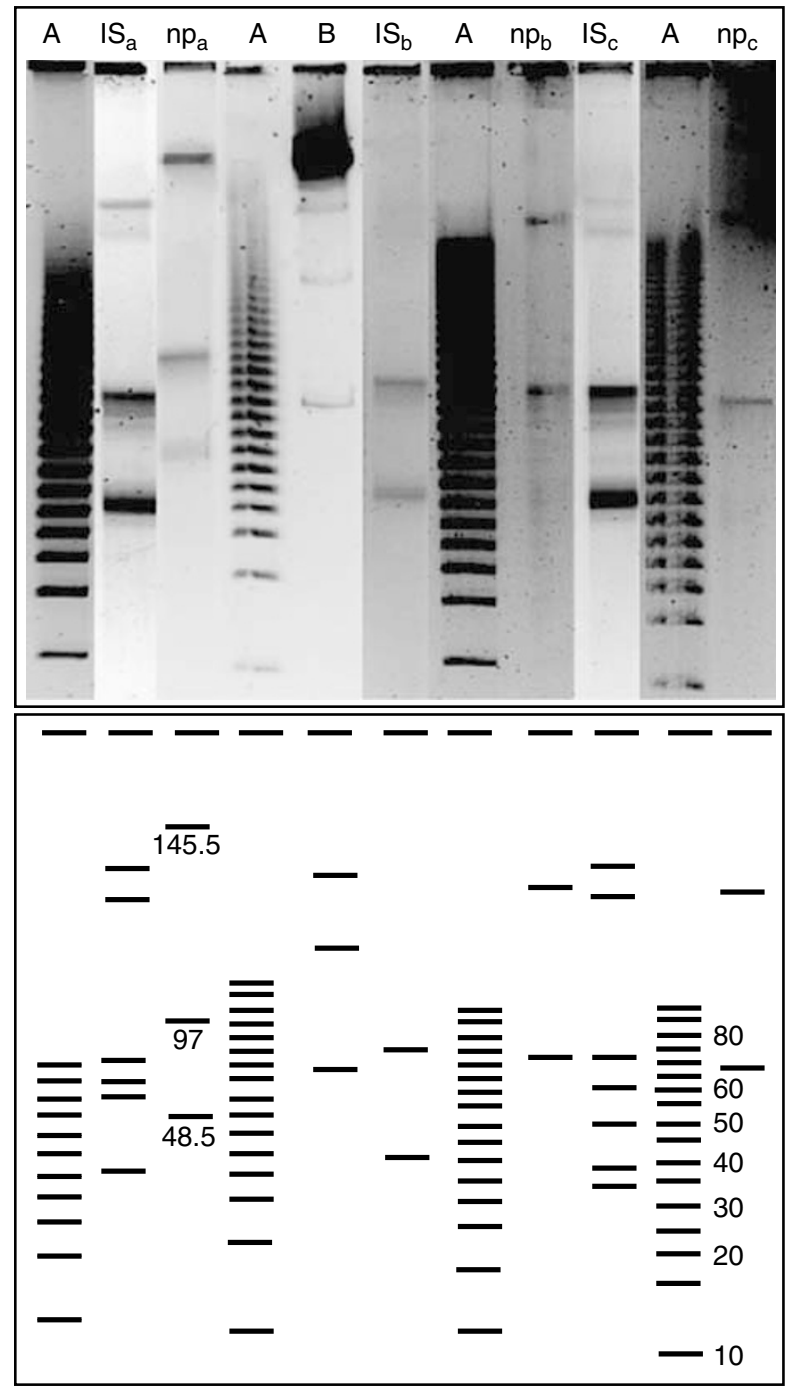

b

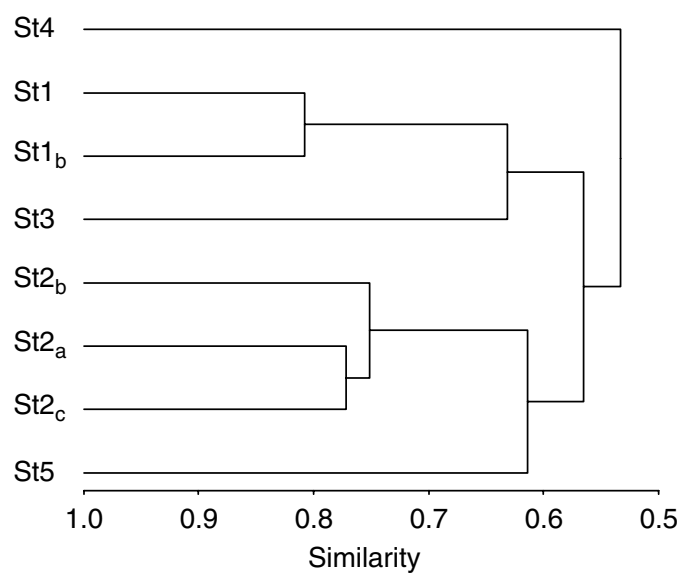




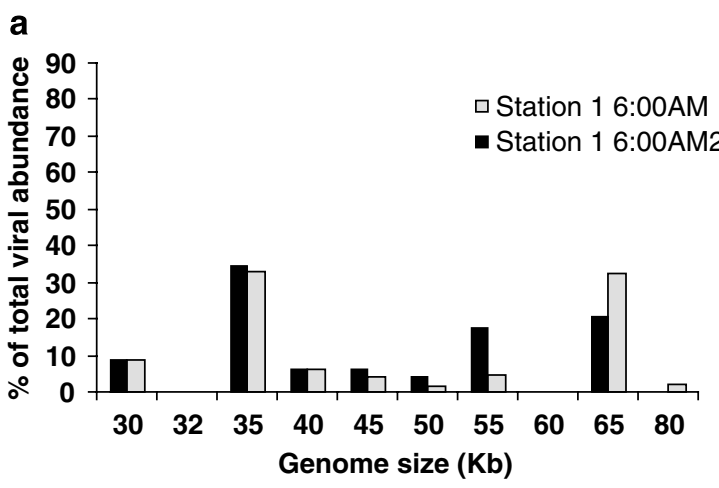

b
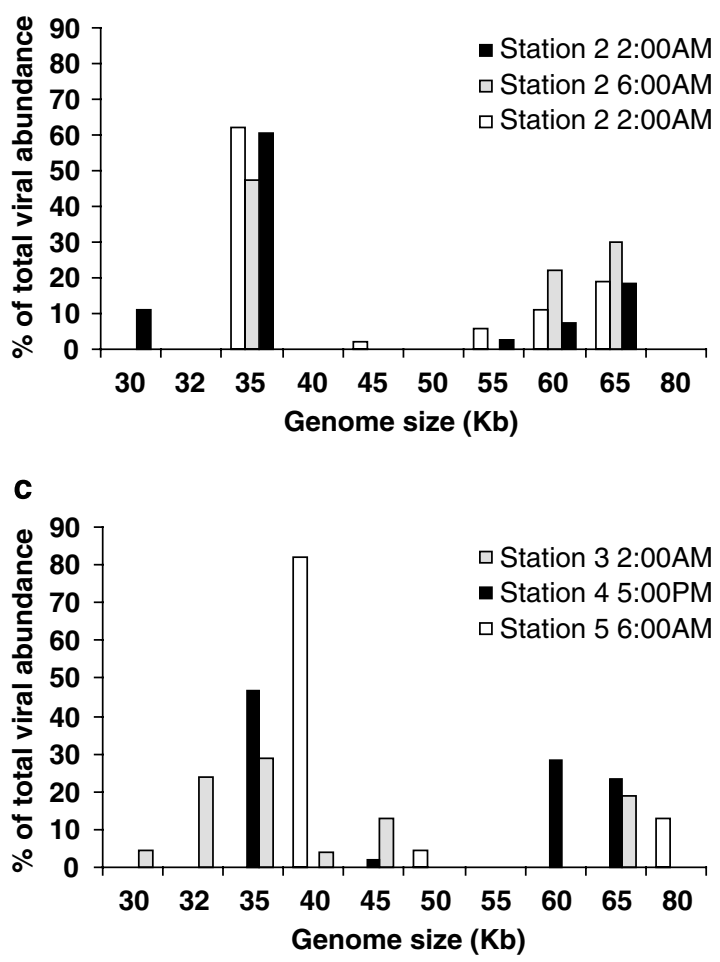

Figure 3 Distribution of the most abundant viral genome sizes obtained from the in situ virioplankton community of the open North Sea collected at St 1 (a), St 2 (b) and Sts 3-5 (c) at different times of the day.

the in situ virioplankton community. Bands of higher kb appeared toward the end of the sampling period (between 25 May and 02 June). Only minor differences in the distribution of newly produced viral genomes over time in the coastal North Sea were found between different dates (Figure 5a). The newly produced viruses of $35 \mathrm{~kb}$ were present throughout the entire sampling period accounting for up to $20 \%$ of the total number of bands and $36 \%$ of the total viral abundance whereas the other viral genomes were produced only on specific days (Figure 6). Bands of 45, 55 and $65 \mathrm{~kb}$ of genome sizes comprised $18 \%$ of the total number of bands and $20 \%, 16 \%$ and $12 \%$, respectively, of the total viral abundances (Figure 6). The differences in a
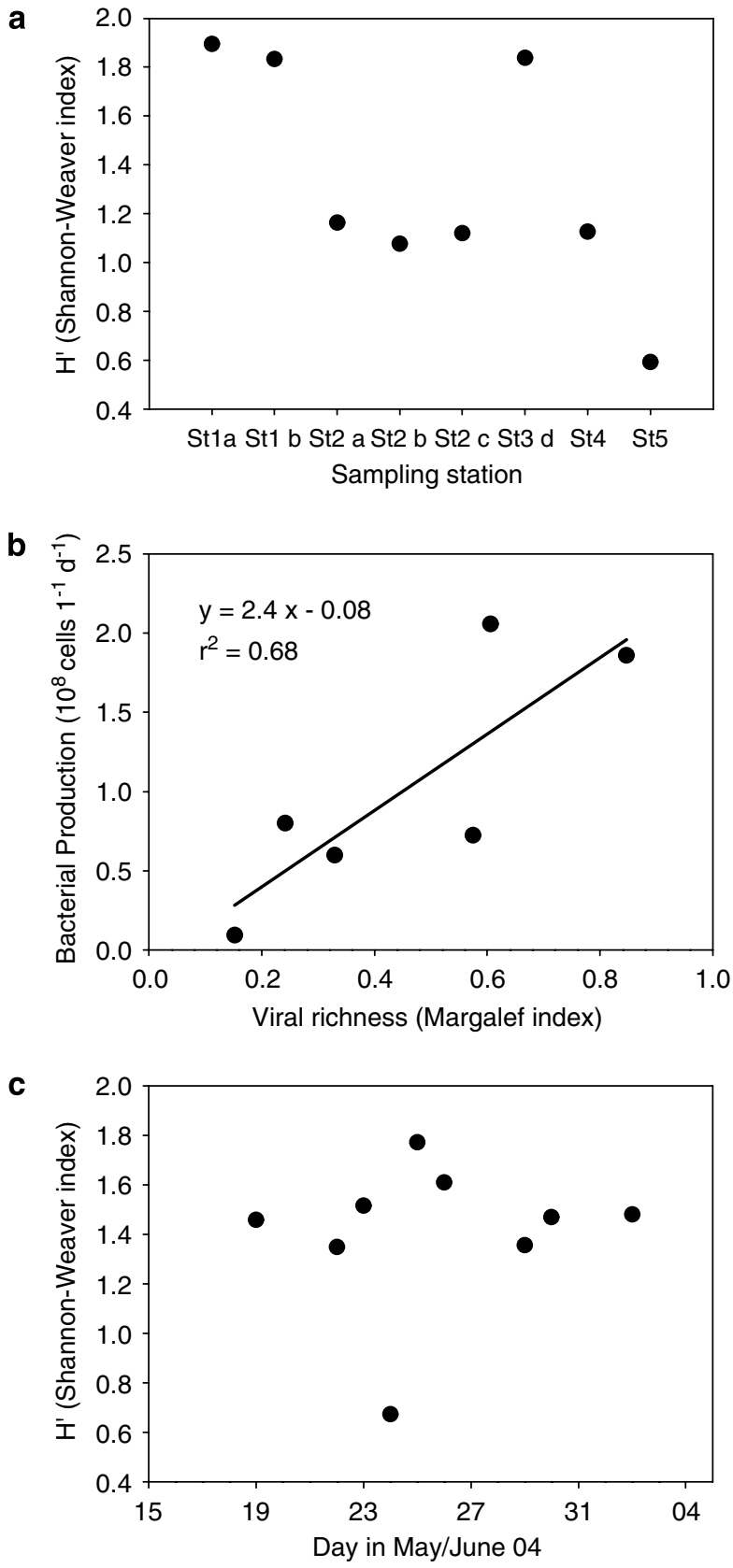

Figure 4 Variability of the Shannon-Weaver index (H') for the open North Sea (a) and the coastal North Sea (c). The relation between viral richness and bacterial production at Sts1-3 is also shown (b). In (a), the subscripts a, b and c indicate the sampling times, 0200, 0600 and 0200 hours (next day), respectively.

fingerprints between consecutive days were statistically not significant (ANOVA on ranks, KruskalWallis, $P=0.092$ ). The newly produced viral community remained similar over consecutive sampling days interrupted by shifts in the community of newly produced viruses (Figure 5b). These results indicate that a specific viral community was produced over periods of 2-4 days followed by substantial changes. 
Table 2 Bacterial and viral parameters obtained for the coastal North Sea

\begin{tabular}{|c|c|c|c|c|c|c|}
\hline Sampling date & $\begin{array}{c}V A \\
\left(10^{10} \text { VLP }\right. \\
\text { per liter })\end{array}$ & $\begin{array}{c}B A \\
\left(10^{10} \text { cells }\right. \\
\text { per liter })\end{array}$ & $V A / B A$ & $\begin{array}{c}V P \\
\left(10^{10} \text { VLP per }\right. \\
\text { liter per day) }\end{array}$ & $\begin{array}{c}V M M \\
\left(10^{10} \text { cells per }\right. \\
\text { liter per day })\end{array}$ & $\begin{array}{l}\text { FIC } \\
(\%)\end{array}$ \\
\hline 22 May & $5.70 \pm 0.2$ & $0.62 \pm 0.01$ & 9 & 35 & 1.67 & 0.37 \\
\hline 23 May & $6.34 \pm 0.5$ & $0.52 \pm 0.02$ & 12 & 1.92 & 0.09 & 5.69 \\
\hline 24 May & $5.45 \pm 0.3$ & $0.49 \pm 0.02$ & 11 & 9.36 & 0.45 & 1.10 \\
\hline 25 May & $8.75 \pm 0.3$ & $0.54 \pm 0.04$ & 16 & 6.00 & 0.29 & 1.89 \\
\hline 26 May & $6.89 \pm 0.7$ & $0.67 \pm 0.01$ & 10 & 1.20 & 0.05 & 11.73 \\
\hline 29 May & $8.75 \pm 0.4$ & $0.32 \pm 0.00$ & 27 & 18 & 0.86 & 0.37 \\
\hline 30 May & $6.86 \pm 0.3$ & $0.46 \pm 0.03$ & 15 & 5.76 & 0.27 & 1.68 \\
\hline 31 May & $7.29 \pm 0.5$ & $0.48 \pm 0.02$ & 15 & 9.36 & 0.44 & 1.08 \\
\hline 1 June & $6.01 \pm 0.4$ & $0.66 \pm 0.02$ & 9 & 11 & 0.52 & 1.26 \\
\hline
\end{tabular}

Abbreviations: BA, bacterial abundance; FIC, frequency of infected cells; VA, viral abundance; VMM, viral-mediated cell mortality; VP, viral production.

Averages and standard errors ( \pm s.e.) of triplicate measurements are given for each date.

Dynamics of virioplankton in aged North Sea water Viral abundance and production. The number of viruses and bacteria remained fairly constant over the sampling days, averaging $2.9 \pm 0.4 \times 10^{9} \mathrm{VLP}$ per liter and $0.4 \pm 0.03 \times 10^{9}$ bacteria per liter, respectively (Table 3). The virus-to-bacteria ratio averaged $7.9 \pm 1.1$, with higher values at high viral lysis rates. The VP was very low compared to the coastal North Sea waters ranging from 0.01 to $1.2 \times 10^{9}$ VLP per liter per day (Table 3).

Dynamics of newly produced viral diversity in aged North Sea water. In the aged North Sea water, the newly produced viral community was generally less diverse than that of the coastal North Sea displaying bands ranging from 40 to $65 \mathrm{~kb}$. However, the fingerprinting pattern during consecutive days changed similarly to that in the coastal North Sea (Figure 7A). The viral genome of $65 \mathrm{~kb}$ was present during the entire sampling period making up $35 \%$ of the total viral genomes whereas the other viruses were produced only on specific days (Figure 7A). Viruses of $40,45,50$ and $55 \mathrm{~kb}$ genome size comprised $16 \%, 26 \%, 5 \%$ and $16 \%$, respectively, of the total viral genomes detected. Production of specific viruses occurred episodically as indicated by considerable dissimilarity between samples collected during consecutive days (Figure 7B).

The Shannon-Weaver index, the evenness and the Margalef's index ranged from 0.67 to 1.37 $(1.05 \pm 0.3)$, from 0.97 to $1.00(0.98 \pm 0.01)$ and from 0.06 to $0.18(0.12 \pm 0.04)$, respectively.

\section{Discussion}

Methodological considerations

Several tests to achieve a better band resolution in the PFGE approach have been carried out prior to processing the samples. In contrast to Steward et al. (2000), increased band sharpness was obtained using ultracentrifugation instead of centrifugal ultrafiltration. As reported earlier (Paul et al.,
1991), a variable amount of viruses is lost during the filtration steps as well as in the ultracentrifugation. In the coastal North Sea, the high concentration of suspended solids might have contributed to the loss of viruses during the virus-harvesting procedure due to adsorption of viruses on silts and clay particles. Another factor influencing the recovery of viruses in the centrifugation step is the type of cartridge used for filtration. In our hands, Vivaflow 200 reached recovery efficiencies of $90 \%$ and ensured the integrity of viruses much better than Pellicon cartridges.

Some samples of newly produced viruses, such as depicted in Figure 5a, displayed wide bands with some smear, mainly around 35 and $65 \mathrm{~kb}$ that could not be optimally separated despite using different settings for PFGE. It can be assumed that this smear was caused by a high number of viruses with very similar to identical genome sizes (Williamson et al., 2001).

\section{Diel cycle in viral infection}

Diel cycles in viral infection of bacterioplankton were reported by Winter et al. (2004) for the open North Sea with higher infection rates during nighttime than during the day. In their study, lysis rates were not measured but FIC (frequency of infected cells) data were used instead (Winter et al., 2004). In the present study, VP in the open North Sea was higher in the early morning and early afternoon than during the rest of the day (Table 1), confirming the diel dynamics in VP reported previously (Winter et al., 2004). Viral abundance tended to be higher during late afternoon and early evening at Sts 1 and 2 (Table 1). Bacterial abundance and production did not follow a distinct diel pattern (Table 1).

\section{Dynamics of viral infection}

Bacterial production was more than two times higher at the southern station (St 1) than at the more northern stations (Sts 2 and 3; Table 1). St 1 

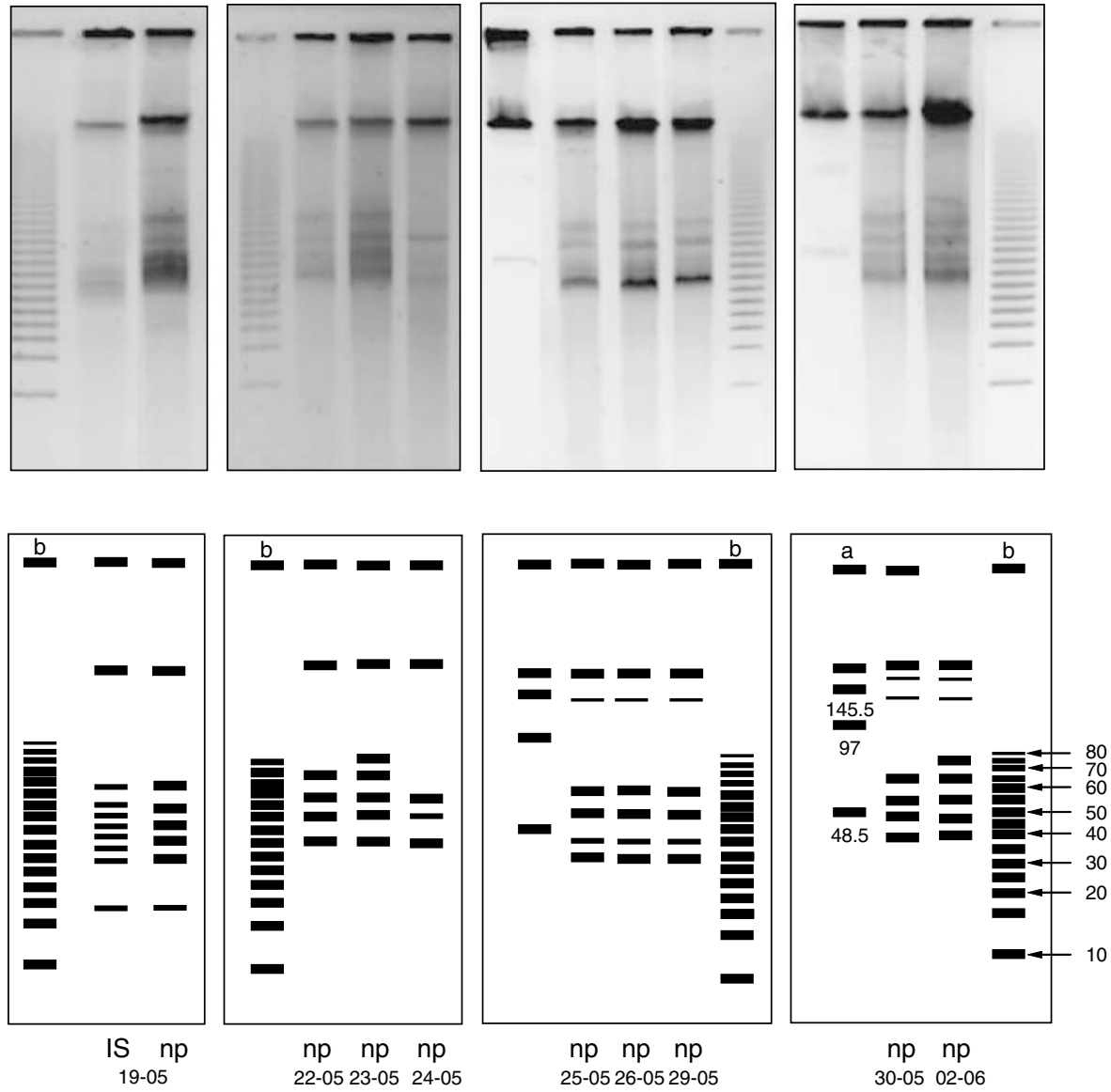

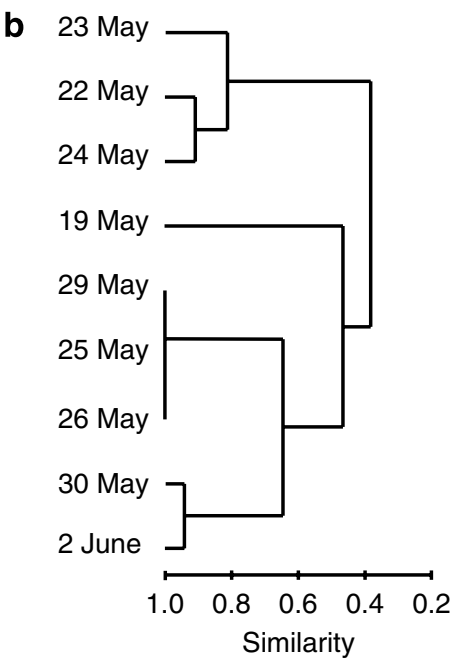

Figure 5 Virioplankton pulsed-field gel electrophoresis (PFGE) fingerprints of the coastal North Sea (upper panel) and their respective computer-generated banding patterns (center panel) analyzed during consecutive days. 'IS' stands for in situ viral diversity (a). The rest of the lanes represents newly produced (np) viruses. Lanes a and b are molecular size markers (in kb). (b) Similarity matrix of virioplankton PFGE fingerprints from the in situ virioplankton community of the coastal North Sea.

displayed a similar dynamic as the coastal North Sea site at the NIOZ jetty (ANOVA on ranks, KruskalWallis, $P=0.034)$. Between $2.1 \times 10^{6}$ and $1.2 \times 10^{9}$ bacteria per liter per day have to be lysed daily to maintain the observed VP, with an average of $1.5 \times 10^{8}$ bacterial cells per liter per day (Table 1 ).
Hence, viral-induced mortality amounted to $6.7 \pm 8.3 \%$ (range, $0.1-26 \%$ ) of the BP (Table 1). This percentage of viral-induced mortality is similar to values reported for other marine systems (Suttle and Chan, 1994; Hwang and Cho, 2002; Wilhelm et al., 2002; Weinbauer et al., 2003). 


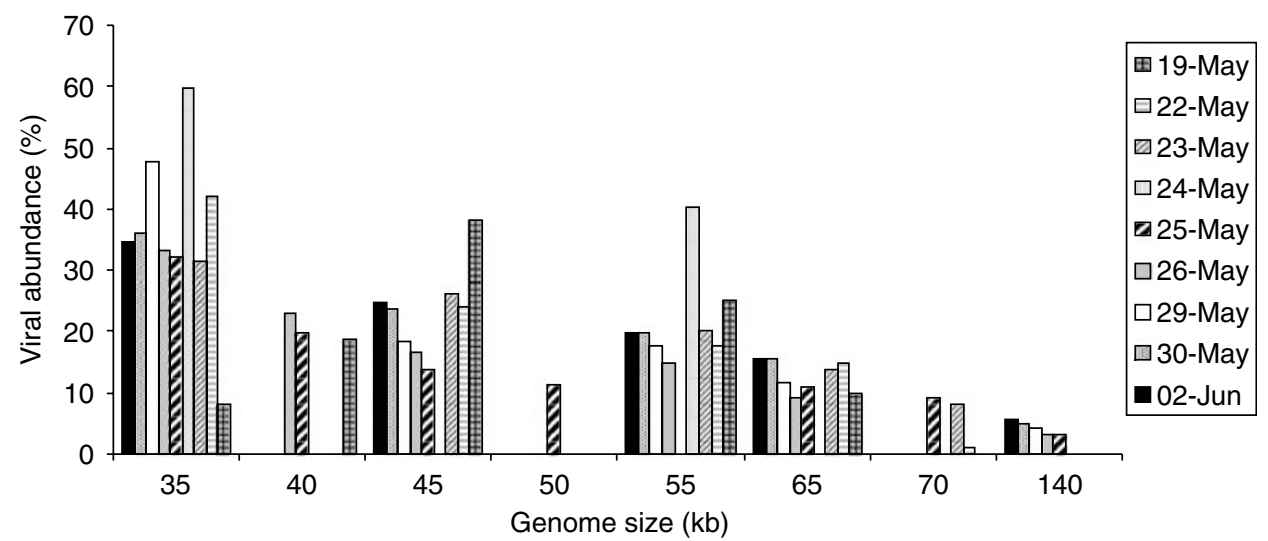

Figure 6 Distribution of the abundance of the genome sizes of newly produced viruses in the coastal North Sea waters obtained over a period of 15 days.

Table 3 Bacterial and viral parameters obtained for the aged North Sea

\begin{tabular}{lcccc}
\hline Sampling date & VA & VA/BA & $\begin{array}{c}\text { VP } \\
\left(10^{9} \text { VLP per liter }\right)\end{array}$ & $\begin{array}{c}B A \\
\left(10^{9} \text { cells per liter }\right)\end{array}$ \\
\hline 6 June & $2.53 \pm 0.2$ & $0.36 \pm 0.02$ & 7.2 & 0.05 \\
7 June & $2.64 \pm 0.1$ & $0.40 \pm 0.02$ & 6.6 & 0.36 \\
8 June & $3.79 \pm 0.3$ & $0.39 \pm 0.01$ & 8.8 & 0.96 \\
9 June & $3.22 \pm 0.4$ & $0.40 \pm 0.3$ & 8.3 & 0.01 \\
13 June & $2.69 \pm 0.1$ & $0.32 \pm 0.02$ & 7.2 & 0.87 \\
14 June & $2.98 \pm 0.2$ & $0.41 \pm 0.01$ & 7.9 & 0.57 \\
Average & 3.00 & 0.40 & & \\
\hline
\end{tabular}

Abbreviations: BA, bacterial abundance; VA, viral abundance; VP, viral production.

Averages and standard errors ( \pm s.e.) of triplicate measurements are given for each date.

As previously published, BS data were used to calculate mortality rates, we might have overestimated host mortality if the actual BS is lower than those used in this study (21-31). The mortality of bacteria calculated for Delaware Bay waters was in the range of $2.4 \times 10^{9}$ to $4.2 \times 10^{9}$ bacteria per liter per day (Helton et al., 2005) and estimates from the Chukchi Sea, also based on VP, ranged between $1.9 \%$ and $12 \%$ of the daily bacterial cell production (Steward et al., 1996). Thus, our estimated bacterial mortality is in the range of values reported for other neritic waters.

VTR and BTR averaged 0.50 and 0.25 per day, respectively (Table 1). Lytic viruses replicate more rapidly within hosts growing in eutrophic than in oligotrophic waters, that is, in faster growing cells (Hewson et al., 2001). A positive correlation between viral and bacterial turnover time was reported for oligotrophic and mesotrophic environments (Steward et al., 1992; Wilhelm et al., 1998; Noble and Fuhrman, 2000; Hwang and Cho, 2002), whereas no such relation was found in our study.

Variability in the dynamics of viral assemblages Generally, in situ viral diversity was fairly stable during the investigation periods in both the coastal and open North Sea (Figures 2 and 4). Diel dynamics in VP were detectable although not pronounced (Table 1), probably due to the low diel dynamics in bacterial activity in the North Sea (Winter et al., 2004). More pronounced diel patterns in bacterioplankton production have been reported for oligotrophic systems such as the Mediterranean Sea (Bettarel et al., 2002). The short-term variability observed in the viral infection cycle in the coastal North Sea as the presence and absence of distinct bands in the newly produced viral populations was evident on a time scale of days (Figure 5). Thus, successions in the bacteriophage community do not occur gradually but in steps with a more stable virioplankton community composition lasting for a few days followed by major shifts in the viral community composition (Figures 2 and 5). Even under the most stable conditions in the aged North Sea water, different newly produced viral populations appeared on specific days (Figure 7).

Variability in the viral genome size

Generally, the distribution of viral genome size (VGs) was very similar in the three types of North Sea waters (Figures 3, 6 and 7). It has been reported previously, that the VGs distribution is rather similar across a wide range of marine systems (Wommack et al., 1999a; Steward et al., 2000). The most 


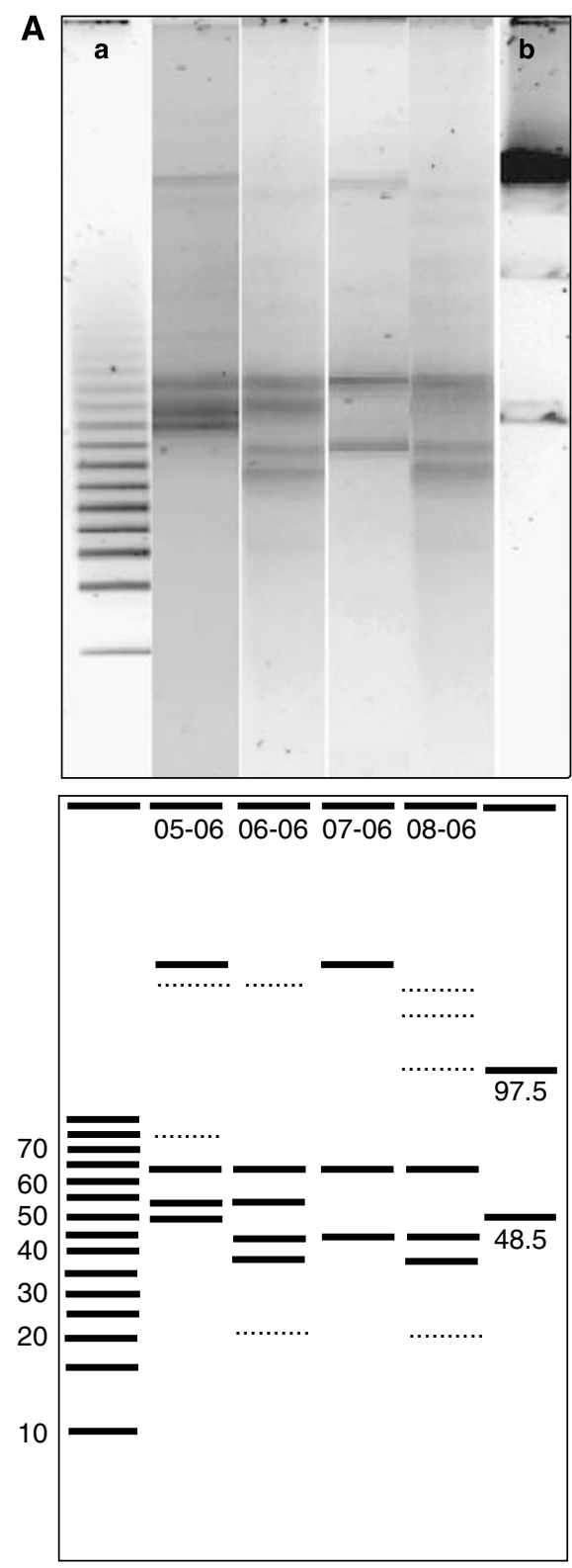

B 5-June

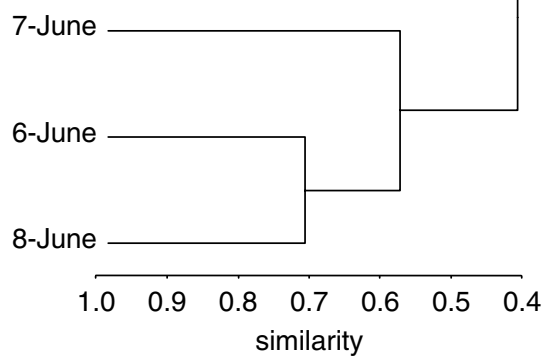

Figure 7 (A) Virioplankton pulsed-field gel electrophoresis (PFGE) fingerprints of aged North Sea water and the corresponding computer-generated banding pattern sampled during consecutive days in June. (B) Similarity matrix of the viral community obtained by PFGE for the different sampling dates. Lanes 'a' and 'b' are molecular size markers (in kb). abundant VGs of newly produced viral populations in open North Sea waters were around 35 and $65 \mathrm{~kb}$, which are typical genome sizes of tailed phages (Ackermann, 2003). This bimodal distribution with major peaks in VGs at around 35 and $65 \mathrm{~kb}$ has been observed also by Steward et al. (2000). Thus, although the viral community is thought to be highly diverse, only two main VGs classes were found to lyse specific target hosts at a given time.

In the coastal North Sea, the newly produced viral assemblage was distributed over a wider range of genome sizes than in the open North Sea. Even in the aged North Sea water, changes in the VGs of newly produced viruses were detectable during consecutive days (Figure 7) indicative for maintained viral and bacterial dynamics even when the number of bacteria remains constant. Such a dynamics in the absence of changes in bacterial abundance has been proposed (Wommack et al., 1999b) but never shown before.

\section{Concluding remarks}

Since several different types of viruses can have the same or a very similar genome size, PFGE provides only a rough minimum estimate of virioplankton diversity and some more subtle changes in the composition of the viral community might not be detectable. Despite these inherent limitations of the PFGE, we have shown that viral richness is quite dynamic, changing on a time scales of hours to days even in presumably stable systems such as aged seawater. Only a limited number of viral populations are produced at any given time in surface waters indicating rapidly changing infection targets, if virus-host specificity is assumed. The main lysis target changes within a few hours in surface waters otherwise the observed diversity of bacteriophages in natural waters would not be maintained given the viral decay rates of 1-2 days.

\section{Acknowledgements}

We thank Corina Brussaard for inviting us to join her cruise and the captain and the crew of the R/V Pelagia for their splendid support and atmosphere on board. The Dutch Marine Research Facilities provided excellent logistic support. Research was supported by two grants from the Dutch Science Foundation, Earth and Life Sciences branch (NWO-ALW project nos. 835.20.023 and 812.03.001. This paper is in partial fulfillment of the requirements for a $\mathrm{PhD}$ degree from the University of Groningen by V.P. The work was carried out within the frame of the 'Networks of Excellence' MarBef and EurOceans supported by the 6th Framework Program of the European Union.

\section{References}

Ackermann HW. (1987). Bacteriophage taxonomy in 1987. Microbiol Sci 4: 214-218.

Ackermann HW. (2003). Bacteriophage observations and evolution. Res Microbiol 154: 245-251. 
Angly FE, Felts B, Breitbart M, Salamon P, Edwards RA, Carlson C et al. (2006). The marine viromes of four oceanic regions. PLoS Biol 4: e368.

Bergh O, Borsheim KY, Bratbak G, Heldal M. (1989). High abundance of viruses found in aquatic environments. Nature 340: 467-468.

Bettarel Y, Dolan JR, Hornak K, Lemee R, Masin M, Pedrotti ML et al. (2002). Strong, weak, and missing links in a microbial community of the NW Mediterranean Sea. FEMS Microb Ecol 42: 451-462.

Breitbart M, Salamon P, Andresen B, Mahaffy JM, Segall AM, Mead D et al. (2002). Genomic analysis of uncultured marine viral communities. Proc Natl Acad Sci USA 99: 14250-14255.

Brussaard CPD. (2004). Optimization of procedures for counting viruses by flow cytometry. Appl Environ Microbiol 70: 1506-1513.

Chen F, Suttle CA. (1995). Amplification of DNA-polymerase gene fragments from viruses infecting microalgae. Appl Environ Microbiol 61: 1274-1278.

Chen F, Suttle CA, Short SM. (1996). Genetic diversity in marine algal virus communities as revealed by sequence analysis of DNA polymerase genes. Appl Environ Microbiol 62: 2869-2874.

Dice LR. (1945). Measures of the amount of ecologic association between species. Ecology 26: 297-302.

Heldal M, Bratbak G. (1991). Production and decay of viruses in aquatic environments. Mar Ecol Prog Ser 72: 205-212.

Helton RR, Cottrell MT, Kirchman DL, Wommack KE. (2005). Evaluation of incubation-based methods for estimating virioplankton production in estuaries. Aquat Microb Ecol 41: 209-219.

Hewson I, Fuhrman JA. (2006). Improved strategy for comparing microbial assemblage fingerprints. Microb Ecol 51: 147-153.

Hewson I, O’Neil JM, Fuhrman JA, Dennison WC. (2001). Virus-like particle distribution and abundance in sediments and overlying waters along eutrophication gradients in two subtropical estuaries. Limnol Oceanogr 46: 1734-1746.

Hwang CY, Cho BC. (2002). Virus-infected bacteria in oligotrophic open waters of the East Sea, Korea. Aquat Microb Ecol 30: 1-9.

Jiang S, Fu W, Chu W, Fuhrman JA. (2003). The vertical distribution and diversity of marine bacteriophage at a station off Southern California. Microb Ecol 45: 399-410.

Klieve AV, Bauchop T. (1988). Morphological diversity of ruminal bacteriophages from sheep and cattle. Appl Environ Microbiol 54: 1637-1641.

Lanoil BD, Carlson CA, Giovannoni SJ. (2000). Bacterial chromosomal painting for in situ monitoring of cultured marine bacteria. Environ Microbiol 2: 654-665.

Ludwig JA, Reynolds JF. (1988). Statistical Ecology, a Primer on Methods and Computing. Wiley Inc: New York.

Magurran AE. (1995). Ecological Diversity and its Measurement. Princeton University: Princeton, New Jersey, USA.

Marie D, Brussaard CPD, Thyrhaug R, Bratbak G, Vaulot D. (1999). Enumeration of marine viruses in culture and natural samples by flow cytometry. Appl Environ Microbiol 65: 45-52.

Moebus K. (1980). A method for the detection of bacteriophages from ocean water. Helgol Meeresunters 34: 1-14.
Noble RT, Fuhrman JA. (2000). Rapid virus production and removal as measured with fluorescently labeled viruses as tracers. Appl Environ Microbiol 66: 3790-3797.

Paul JH (ed.) (2001). Methods in Microbiology, Marine Microbiology. Academic Press: London, UK.

Paul JH, Jiang SC, Rose JB. (1991). Concentration of viruses and dissolved DNA from aquatic environments by vortex flow filtration. Appl Environ Microbiol 57: 2197-2204.

Riemann L, Middelboe M. (2002). Stability of bacterial and viral community compositions in Danish coastal waters as depicted by DNA fingerprinting techniques. Aquat Microb Ecol 27: 219-232.

Steward GF, Cochlan WP, Smith DC, Azam F. (1992). Estimation of virus production in the sea: II. field results. Mar Microb Food Webs 6: 79-90.

Steward GF, Montiel JL, Azam F. (2000). Genome size distributions indicate variability and similarities among marine viral assemblages from diverse environments. Limnol Oceanogr 45: 1697-1706.

Steward GF, Smith DC, Azam F. (1996). Abundance and production of bacteria and viruses in the Bering and Chukchi Seas. Mar Ecol Progr Ser 131: 287-300.

Suttle CA, Chan AM. (1994). Dynamics and distribution of cyanophages and their effect on marine Synechococcus spp. Appl Environ Microbiol 60: 3167-3174.

Thingstad TF, Lignell R. (1997). Theoretical models for the control of bacterial growth rate, abundance, diversity and carbon demand. Aquat Microb Ecol 13: 19-27.

Weinbauer MG. (2004). Ecology of prokaryotic viruses. FEMS Microbiol Rev 28: 127-181.

Weinbauer MG, Brettar I, Höfle MG. (2003). Lysogeny and virus-induced mortality of bacterioplankton in surface, deep, and anoxic marine waters. Limnol Oceanogr 48: 1457-1465.

Weinbauer MG, Suttle CA. (1996). Potential significance of lysogeny to bacteriophage production and bacterial mortality in coastal waters of the Gulf of Mexico. Appl Environ Microbiol 62: 4374-4380.

Whittaker RH. (1952). A study of summer foliage insect communities in the Great Smoky Mountains. Ecological Monogr 22: 1-44.

Wilhelm SW, Brigden SM, Suttle CA. (2002). A dilution technique for the direct measurement of viral production: a comparison in stratified and tidally mixed coastal waters. Microb Ecol 43: 168-173.

Wilhelm SW, Weinbauer MG, Suttle CA, Jeffrey WH. (1998). The role of sunlight in the removal and repair of viruses in the sea. Limnol Oceanogr 43: 586-592.

Williamson SJ, McLaughlin MR, Paul JH. (2001). Interaction of the Phi HSIC virus with its host: lysogeny or pseudolysogeny? Appl Environ Microbiol 67: 1682-1688.

Winget DM, Williamson KE, Helton RR, Wommack KE. (2005). Tangential flow diafiltration: an improved technique for estimation of virioplankton production. Aquat Microb Ecol 41: 221-232.

Winter C, Herndl GJ, Weinbauer MG. (2004). Diel cycles in viral infection of bacterioplankton in the North Sea. Aquat Microb Ecol 35: 207-216.

Wommack KE, Ravel J, Hill RT, Chun JS, Colwell RR. (1999a). Population dynamics of Chesapeake Bay virioplankton: total-community analysis by pulsed-field gel electrophoresis. Appl Environ Microbiol 65: 231-240.

Wommack KE, Ravel J, Hill RT, Colwell RR. (1999b). Hybridization analysis of Chesapeake Bay virioplankton. Appl Environ Microbiol 65: 241-250. 